\title{
Progesterone metabolites regulate induction, growth, and suppression of estrogen- and progesterone receptor-negative human breast cell tumors
}

John P Wiebe ${ }^{1 *}$, Guihua Zhang ${ }^{1,2}$, lan Welch $^{3}$ and Heather-Anne T Cadieux-Pitre ${ }^{4}$

\begin{abstract}
Introduction: Of the nearly 1.4 million new cases of breast cancer diagnosed each year, a large proportion is characterized as hormone receptor negative, lacking estrogen receptors (ER) and/or progesterone receptors (PR). Patients with receptor-negative tumors do not respond to current steroid hormone-based therapies and generally have significantly higher risk of recurrence and mortality compared with patients with tumors that are ER- and/or PR-positive. Previous in vitro studies had shown that the progesterone metabolites, $5 \alpha$-dihydroprogesterone ( $5 \alpha \mathrm{P}$ )

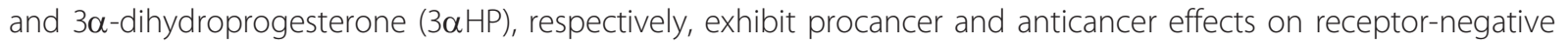
human breast cell lines. Here in vivo studies were conducted to investigate the ability of $5 \alpha \mathrm{P}$ and $3 \alpha \mathrm{HP}$ to control initiation, growth, and regression of ER/PR-negative human breast cell tumors.
\end{abstract}

Methods: ER/PR-negative human breast cells (MDA-MB-231) were implanted into mammary fat pads of immunosuppressed mice, and the effects of $5 \alpha \mathrm{P}$ and $3 \alpha \mathrm{HP}$ treatments on tumor initiation, growth, suppression/ regression, and histopathology were assessed in five separate experiments. Specific radioimmunoassays and gas chromatography-mass spectrometry were used to measure $5 \alpha \mathrm{P}, 3 \alpha \mathrm{HP}$, and progesterone in mouse serum and tumors.

Results: Onset and growth of ER/PR-negative human breast cell tumors were significantly stimulated by $5 \alpha \mathrm{P}$ and inhibited by $3 \alpha \mathrm{HP}$. When both hormones were applied simultaneously, the stimulatory effects of $5 \alpha \mathrm{P}$ were abrogated by the inhibitory effects of $3 \alpha \mathrm{HP}$ and vice versa. Treatment with $3 \alpha \mathrm{HP}$ subsequent to $5 \alpha$ P-induced tumor initiation resulted in suppression of further tumorigenesis and regression of existing tumors. The levels of $5 \alpha \mathrm{P}$ in tumors, regardless of treatment, were about 10-fold higher than the levels of $3 \alpha \mathrm{HP}$, and the $5 \alpha \mathrm{P}: 3 \alpha \mathrm{HP}$ ratios were about fivefold higher than in serum, indicating significant changes in endogenous synthesis of these hormones in tumorous breast tissues.

Conclusions: The studies showed that estrogen/progesterone-insensitive breast tumors are sensitive to, and controlled by, the progesterone metabolites $5 \alpha \mathrm{P}$ and $3 \alpha \mathrm{HP}$. Tumorigenesis of ER/PR-negative breast cells is significantly enhanced by $5 \alpha \mathrm{P}$ and suppressed by $3 \alpha \mathrm{HP}$, the outcome depending on the relative concentrations of these two hormones in the microenvironment in the breast regions. The findings show that the production of $5 \alpha \mathrm{P}$ greatly exceeds that of $3 \alpha \mathrm{HP}$ in ER/PR-negative tumors and that treatment with $3 \alpha \mathrm{HP}$ can effectively block tumorigenesis and cause existing tumors to regress. The results provide the first hormonal theory to explain

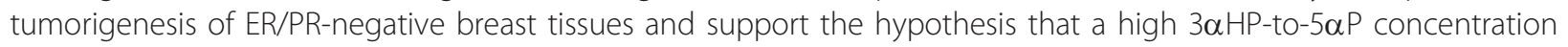
ratio in the microenvironment may foster normalcy in noncancerous breast regions. The findings suggest new diagnostics based on the relative levels of these hormones and new approaches to prevention and treatment of

\footnotetext{
* Correspondence: jwiebe@uwo.ca

'Department of Biology, The University of Western Ontario, London, Ontario, N6A5B7 Canada

Full list of author information is available at the end of the article
} 
breast cancers based on regulating the levels and action mechanisms of anti- and pro-cancer progesterone metabolites.

Keywords: Breast cancer, ER/PR-negative breast cancers, hormonal control, microenvironment, progesterone metabolites, $5 \alpha$ ?a?-dihydroprogesterone, 3a?a?-dihydroprogesterone, tumorigenesis, tumor promoter and suppressor hormones, biomarkers, normalcy

\section{Introduction}

Breast cancer is the most frequently diagnosed cancer and the leading cause of cancer death in women worldwide, with nearly 1.4 million new cases annually [1]. Progesterone and estrogens have long been linked to breast cancer $[2,3]$, and current understanding of the effective actions of these hormones implies the presence of receptors (ER and PR) in the target cells $[4,5]$. However, a large proportion (about $30 \%$ to $60 \%$ ) of breast tumors are ER and/or PR negative [4,6-8], and about $90 \%$ of normal proliferating breast epithelial cells are receptor negative [9]. Patients with receptor-negative tumors generally show lack of response to adjuvant hormone therapy and have significantly higher risk of mortality compared with patients with tumors that are ER and/or PR positive [10-14]. Overall, this means that for receptor-negative breast cancers, current explanations based on estrogen and progesterone actions and receptors are inadequate, and the related hormone-based therapies are ineffective. Here evidence is presented that the progesterone metabolites, $5 \alpha$-pregnane-3,20-dione

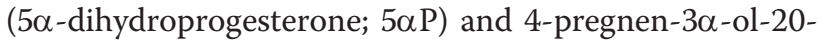
one ( $3 \alpha$-dihydroprogesterone; $3 \alpha \mathrm{HP}$ ), can regulate ER/ PR-negative breast cell tumor formation and growth as well as tumor regression and maintenance of normalcy.

Our previous in vitro studies had shown that breast tissues and cell lines readily convert progesterone to $5 \alpha-$ pregnanes, such as $5 \alpha \mathrm{P}$, and delta-4-pregnenes, such as $3 \alpha \mathrm{HP}$ (Figure 1), and that tumorous breast tissues [15] and tumorigenic breast cell lines [16] produce higher levels of $5 \alpha \mathrm{P}$ and lower levels of $3 \alpha \mathrm{HP}$ than do normal breast tissues and nontumorigenic cell lines. The differences in progesterone metabolism between normal and tumorous breasts were observed in all breast tissue samples examined, regardless of the ages of the women, subtypes and grades of carcinomas, and whether the tissues were ER and PR positive and/or negative [15]. The progesterone metabolism studies suggested that increases in $5 \alpha \mathrm{P}$ and decreases in $3 \alpha \mathrm{HP}$ production accompany the shift toward breast cell neoplasia and tumorigenicity [17]. In vitro studies on five different human breast cell lines showed that cell proliferation and detachment are significantly increased by $5 \alpha \mathrm{P}$ and decreased by $3 \alpha \mathrm{HP}[15,18]$. The opposing in vitro effects of $5 \alpha \mathrm{P}$ and $3 \alpha \mathrm{HP}$ were observed in all breast cells studied: tumorigenic and nontumorigenic, estrogen-responsive and unresponsive, and ER/PR-positive and -negative cells [18].

The objectives of the current studies were (a) to determine whether the progesterone metabolites, $5 \alpha \mathrm{P}$ and $3 \alpha \mathrm{HP}$, have the ability to regulate in vivo induction and growth of ER/PR-negative human breast cancer cell tumors in mice, and (b) to determine the relative concentrations of $5 \alpha \mathrm{P}$ and $3 \alpha \mathrm{HP}$ in serum of tumorous and nontumorous mice and within tumors. The studies provide the first in vivo evidence that initiation and growth of ER/PR-negative human breast cell tumors are markedly stimulated by $5 \alpha \mathrm{P}$ and suppressed by $3 \alpha \mathrm{HP}$, and

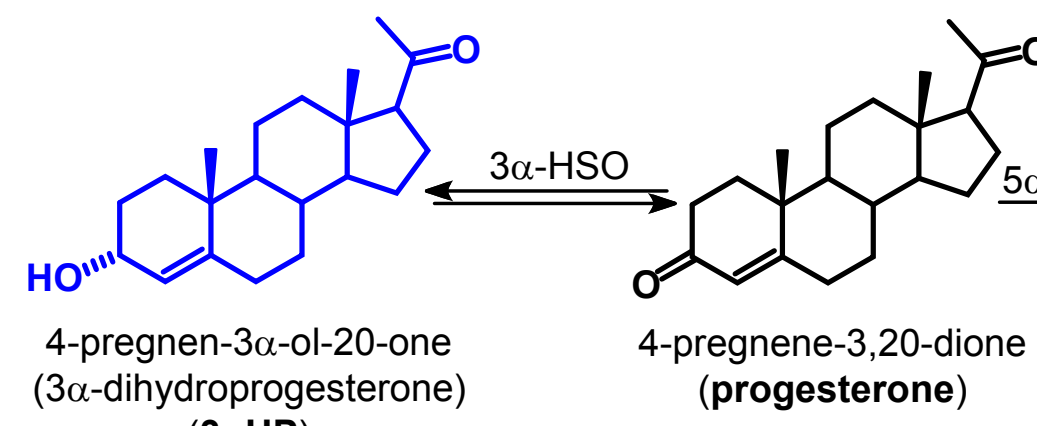

$(3 \alpha \mathrm{HP})$

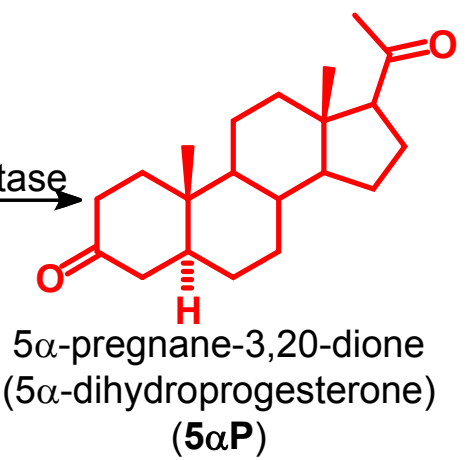

$(5 \alpha \mathbf{P})$

Figure 1 Conversion of progesterone to $3 \alpha$-dihydroprogesterone $(3 \alpha \mathrm{HP})$ and $5 \alpha$-dihydroprogesterone $(5 \alpha \mathrm{P})$. In vitro studies have shown that both ER/PR-positive and -negative human breast tissues and cell lines are able to convert progesterone to $3 \alpha \mathrm{HP}$ and $5 \alpha \mathrm{P}$ by the actions of $3 \alpha$-hydroxysteroid oxidoreductase ( $3 \alpha-\mathrm{HSO})$ and $5 \alpha$-reductase, respectively. 
that established $5 \alpha \mathrm{P}$-induced tumors can be regressed by treatment with $3 \alpha \mathrm{HP}$. Measurements of their levels indicate that the relative concentrations in the breast microenvironment of the progesterone metabolites determine whether ER/PR-negative cells are stimulated toward neoplasia and tumorigenesis or regulated to maintain a normal state.

\section{Methods and materials}

\section{Chemicals and reagents}

Progesterone, $5 \alpha \mathrm{P}$, cell-culture media, insulin, penicillin, and streptomycin were obtained from Sigma Chemical Co. (Oakville, ON, Canada). $3 \alpha \mathrm{HP}$ was obtained from Steraloids (Newport, RI, USA). Serum was purchased from Invitrogen (Burlington, ON, Canada). $\left[1,2,6,7-{ }^{3} \mathrm{H}\right]$ Progesterone and $\left[9,11,12-{ }^{3} \mathrm{H}\right] 5 \alpha$-pregnan-3 $\alpha$-ol-20-one were purchased from Perkin-Elmer (Woodbridge, ON, Canada). Other chemicals and solvents were of appropriate analytic grade and were purchased from Sigma Chemical Co., BDH Inc., (Toronto, ON, Canada), VWR (Mississauga, ON, Canada), or Fisher Scientific Ltd. (Toronto, ON, Canada). Ethanol was double (glass) distilled.

\section{Cells}

The human breast cell line MDA-MB-231 was obtained from American Type Culture Collection (ATCC, Manassas, VA, USA), and cells were grown in a 1:1 Ham F12 Medium and Dulbecco Modified Eagle Medium with supplements and $10 \%$ calf serum as described [18]. Cells were grown in T-75 flasks (Sarstedt) and were harvested at approximately $80 \%$ confluence. Cell-proliferation and -detachment responses to $5 \alpha \mathrm{P}$ and $3 \alpha \mathrm{HP}$ were tested [15] before harvesting for inoculation into animals, and cell viability was determined with the trypan blue exclusion test. Cells intended for inoculation into mice were harvested, washed, and then suspended in serum-free medium (about $5 \times 10^{6}$ cells per $100 \mu \mathrm{l}$ ).

\section{Animals}

Severe combined immunodeficiency (SCID) female mice with impaired $\mathrm{T}$ - and B-cell lymphocyte development (NOD SCID) were obtained from Charles River Laboratories (Saint-Constant, Quebec, Canada) at 5 to 6 weeks of age and maintained under specific pathogen-free conditions with food and water ad libitum. All animal handling and procedures were approved by Western University Institutional Care and Use Committee. After acclimation (8 to 27 days), cells were implanted on day 0 . Each mouse was anesthetized with a mixture of isofluorane and oxygen, and about $5 \times 10^{6}$ cells, suspended in $100 \mu \mathrm{l}$ cold $\left(0^{\circ} \mathrm{C}\right.$ to $\left.4^{\circ} \mathrm{C}\right)$ serum-free medium, were injected into the right thoracic mammary fat pad through a $5-\mathrm{mm}$ incision at the sternum region, by using a $1.0-\mathrm{ml}$ syringe with 26 - gauge needle. The wound was closed in one layer with metal wound clips or with tissue adhesive (3M Vetbond; St. Paul, MN, USA). The surgical, injection, and handling procedures were conducted in approved laminar-flow sterility hoods. At termination (asphyxiation by $\mathrm{CO}_{2}$ ), blood was collected, tumors were excised and weighed, necropsies were conducted, and tissues were fixed in 10\% formalin for histopathologic observation $(5-\mu \mathrm{m}$ sections, hematoxylin and eosin). Some tumors were stored in methanol for steroid extraction.

\section{Treatments}

Suspensions of $5 \alpha \mathrm{P}$ and $3 \alpha \mathrm{HP}$ were prepared under sterile conditions in sterile-filtered vehicle $(0.9 \% \mathrm{NaCl}$ in double-distilled $\mathrm{H}_{2} \mathrm{O}$, containing $0.1 \%$ double-distilled ethanol and $0.05 \%$ Tween 80 ) at 4 to $5 \mathrm{mg} / 150 \mu \mathrm{l}$. The suspensions were stored at $4{ }^{\circ} \mathrm{C}$ before use and were administered SC (150 $\mu \mathrm{l} /$ injection) by using a 1.0 -ml syringe with a 23-gauge needle in the nape of the neck.

\section{Tumor growth monitoring}

The growth of tumors was monitored at regular intervals (weekly at first, and after appearance of palpable tumors, every second day or every day). Tumor volumes were determined from digital caliper measurements of length and width. The formula (length $\left.\times(\text { width })^{2} \times 0.6\right)$ was determined to be a good approximation of tumor volumes $\left(\mathrm{mm}^{3}\right)$ as calculated empirically by water-displacement measurements of various irregular tumorlike shapes and sizes of modeling clay.

\section{Synthesis of $\left[{ }^{3} \mathrm{H}\right]-5 \alpha \mathrm{P}$ and $5 \alpha \mathrm{P}-\mathrm{BSA}$ conjugate}

$\left[9,11,12-{ }^{3} \mathrm{H}\right] 5 \alpha \mathrm{P}$ was prepared by oxidation of $\left[9,11,12-{ }^{3} \mathrm{H}\right]$ $5 \alpha$-pregnan-3 $\alpha$-ol-20-one, as described [19]. Purification of $\left[{ }^{3} \mathrm{H}\right]$-labeled $5 \alpha \mathrm{P}$ was by high-pressure liquid chromatography (HPLC; $\mathrm{C}_{18}$ column and methanol/water, 3:1) and TLC (Fisherbrand silica gel GF; three runs in hexane:ethyl acetate, 5:2) $[19,20]$. Preparation of $5 \alpha$-pregnane-3,20dione-11 $\alpha$-hemisuccinate-BSA ( $5 \alpha \mathrm{P}$-BSA conjugate) was by previously described procedures $[21,22]$, and purity of the conjugate was confirmed with HPLC in the solvent system acetonitrile: $\mathrm{H}_{2} \mathrm{O}$ :trifluoroacetic acid (45:55:0.1) by using a Vydac $\mathrm{C}_{4}$ column $(4.6 \times 250 \mathrm{~mm})$ for protein with particle size, $5 \mu \mathrm{m}$, and pore diameter, $300 \mathrm{~A}$.

\section{Synthesis of $\left[{ }^{3} \mathrm{H}\right] 3 \alpha \mathrm{HP}$}

Tritiated $3 \alpha \mathrm{HP}\left(\left[1,2,6,7-{ }^{3} \mathrm{H}\right] 3 \alpha \mathrm{HP}\right)$ was prepared from freshly TLC-cleaned $\left[1,2,6,7-{ }^{3} \mathrm{H}\right]$ progesterone by using potassium trisamylborohydride (KS-Selectride; Aldrich) as reducing agent, as described [20,23], with some modifications. In brief, $\left[{ }^{3} \mathrm{H}\right]$ progesterone $(50$ to $100 \mu \mathrm{Ci})$ was transferred to a dry siliconized reaction tube; the ethanol was evaporated under $\mathrm{N}_{2}$, and the tube was dried overnight in 
a vacuum desiccator over gypsum (Drierite). Dry molecular sieves (3 to 4 ) were added to the tube under an $\mathrm{N}_{2}$ cone, and the tube was sealed with a rubber septum. Dry tetrahydrofuran (THF; $200 \mu \mathrm{l}$ ) was added, and the $\mathrm{N}_{2}$-purged tube was cooled to $-80^{\circ} \mathrm{C}$. The reaction was initiated at $-80^{\circ} \mathrm{C}$ with slow dropwise addition of cold KSSelectride $(100 \mu \mathrm{l})$ under an $\mathrm{N}_{2}$-purged atmosphere and with gentle agitation. After 1 hour, the reaction was continued in an ice bath $\left(0^{\circ} \mathrm{C}\right)$ for another 3 hours and terminated with the addition of $1.0 \mathrm{ml}$ THF and $1.5 \mathrm{ml}$ cold $\left(0^{\circ}\right.$ C) $0.1 \mathrm{~N} \mathrm{NaOH}$. The reaction mixture was extracted 3 times with $5 \mathrm{ml}$ ethyl ether or ether: $\mathrm{CH}_{2} \mathrm{Cl}_{2}$ (5:1) and cleaned by backwashing and $\mathrm{C}_{18}$ bonded silica gel columns. The reaction products were separated and purified with TLC and HPLC, as described earlier under Synthesis of $\left[{ }^{3} \mathrm{H}\right]-5 \alpha \mathrm{P}$, and $\left[{ }^{3} \mathrm{H}\right] 3 \alpha \mathrm{HP}$ was stored in double-distilled ethanol (purged under $\mathrm{N}_{2}$ ), at $-20^{\circ} \mathrm{C}$.

\section{Preparation of antisera}

The $3 \alpha \mathrm{HP}$ antiserum (lyophilized) was from our stock originally generated in rabbits by using a $3 \alpha \mathrm{HP}$-carboxymethyloxime-BSA conjugate [20]. For the preparation of $5 \alpha \mathrm{P}$ and progesterone antiserum, two male SPF New Zealand white rabbits were immunized with $5 \alpha \mathrm{P}-\mathrm{BSA}$, and titer was determined. The serum was stored at $-80^{\circ} \mathrm{C}$. The antiserum from Rabbit 1 showed high specificity for $5 \alpha \mathrm{P}$, and low cross reaction (percentage relative to $5 \alpha \mathrm{P}$ at $100 \%)$ with progesterone $(2.2 \%), 3 \alpha \mathrm{HP}(1.3 \%)$, estradiol (2.2\%), 4-pregnen-20 $\alpha$-ol-3-one (0.9\%), and other $5 \alpha$-pregnanes and testosterone $(<0.1 \%)$. The serum from Rabbit 2 had lower specificity for $5 \alpha \mathrm{P}$ but acceptable specificity for progesterone and was therefore used for the progesterone radioimmunoassay (RIA).

\section{Steroid extractions from serum and tumor tissues}

Sera $(100$ to $300 \mu \mathrm{l})$ from 29 mice from different experiments were extracted 3 times with $2.0 \mathrm{ml}$ ether/chloroform (6:1). The water and organic solvent phases were separated by freezing $\left(-80^{\circ} \mathrm{C}\right)$, the combined solvent portions were dried down under a stream of $\mathrm{N}_{2}$, and the residue was brought up in $0.5 \mathrm{ml}$ of methanol $/ \mathrm{CH}_{2} \mathrm{Cl}_{2}$ (5:1), purged with $\mathrm{N}_{2}$, and stored at $-20^{\circ} \mathrm{C}$ until chromatography was performed. Tumors were weighed, cut into pieces, and homogenized in 5-ml methanol by using a Polytron and extracted with methanol and 3 times with ether $/ \mathrm{CH}_{2} \mathrm{Cl}_{2}$ (5:1). The combined solvent was evaporated under $\mathrm{N}_{2}$, and the samples brought up in methanol $/ \mathrm{CH}_{2} \mathrm{Cl}_{2}$ (5:1) were cleaned by solid-phase extraction $\left(\mathrm{C}_{18}\right.$-bonded silica gel columns) [20] by using methanol/ $\mathrm{CH}_{2} \mathrm{Cl}_{2}$ (20:1) as eluant at a flow rate of about $0.8 \mathrm{ml} / \mathrm{min}$. The fractions containing the steroids were combined, evaporated under $\mathrm{N}_{2}$, and brought up in $0.5 \mathrm{ml}$ methanol $/ \mathrm{CH}_{2} \mathrm{Cl}_{2}$ (5:1), purged with $\mathrm{N}_{2}$, and stored at $-20^{\circ} \mathrm{C}$ until chromatography.

\section{Chromatographic separation of progesterone, $5 \alpha \mathrm{P}$, and $3 \alpha \mathrm{HP}$}

Thin-layer chromatography (TLC) of serum and tumor extracts was performed on $20 \times 20$-cm silica gel $G(F)$ TLC plates $(250 \mu \mathrm{m}$; Fisher Scientific, Pittsburgh, PA, USA). Extracts and standards ( $5 \alpha \mathrm{P}, 3 \alpha \mathrm{HP}$, progesterone) were run in separate lanes $(2 \times)$ in a solvent system consisting of hexane/chloroform/ethyl acetate (60:60:30). The standards were located by UV absorption and exposure to iodine vapors and, on average, were located at $\mathrm{Rf}$ of $0.62(5 \alpha \mathrm{P}), 0.44$ (progesterone), and $0.27(3 \alpha \mathrm{HP})$. Regions in the sample lanes coinciding with the standards were extracted with ether/chloroform (6:1); the extracts were evaporated under $\mathrm{N}_{2}$ and brought up in 0.4-ml double-distilled ethanol.

\section{Radioimmunoassays}

The RIAs for $5 \alpha \mathrm{P}, 3 \alpha \mathrm{HP}$, and progesterone were basically as described [20], with the generated antisera (see earlier) and scintillation spectrometry (Beckman-Coulter LS 6500 Scintillation Counter). For purposes of comparison, concentrations were standardized to nanograms per milliliter for serum and nanograms per gram for tumors, and it was assumed that these two measures represent a reasonable equivalence.

\section{Mass spectrometry}

For verification of RIA measurements of $5 \alpha \mathrm{P}, 3 \alpha \mathrm{HP}$, and progesterone, portions of TLC-separated extracts from four tumor tissues were tested with both RIA and GC/ MS (Hewlett-Packard GC-Mass Spectrometer, model 5790A/5970A, used in the selected ion mode (SIM) with a DB-1MS $12-\mathrm{m} \times 0.2 \mathrm{~mm} \times 0.33 \mu \mathrm{m}$ cross-linked methyl silicone capillary column). The conditions were similar to those described previously [20]: splitless mode, $0.7 \mathrm{~kg} / \mathrm{cm}^{2}$ helium, $230^{\circ} \mathrm{C}$ injection temperature, column temperature at $150^{\circ} \mathrm{C}$ (initial) to $230^{\circ} \mathrm{C}$ at $20^{\circ} / \mathrm{min}$, and scan speed of $690 \mathrm{amu} / \mathrm{sec}$ at an electron multiplier setting of 2,200 V. Underivatized authentic standards at various concentrations as well as samples were brought up in $10 \mu \mathrm{MeOH}$ or $\mathrm{CH}_{2} \mathrm{Cl}_{2}$, and $5 \mu \mathrm{l}$ was injected for each $\mathrm{GC} / \mathrm{MS}$ analysis. The authentic steroids were first run in standard mode, which showed that, under the condition employed, $5 \alpha \mathrm{P}$ and progesterone each eluted as single peaks (at about 12.5 and 14.2 minutes, respectively), and $3 \alpha \mathrm{HP}$ eluted as three separate peaks consisting of two isomeric dehydrated moieties and whole $3 \alpha \mathrm{HP}$ (at 7.6, 8.3, and 11.1 minutes, respectively) (see Additional file 1A). The runs in standard mode also showed that the major ions $(\mathrm{m} / \mathrm{e})$ were $246,283,298$, and 316 , for $3 \alpha \mathrm{HP}$ and its two dehydrated fragments; 231, 258, 298, and 316 for $5 \alpha \mathrm{P}$; and 124, 229, 272, and 314 for progesterone (Additional file 1B through E). Authentic steroids and 
sample extracts were then run in SIM set for the respective major ions. Quantification of samples was calculated by comparison with concentration curves developed from standards (range of 0.04 to $20 \mathrm{ng}$ ), and the limit of detection was about $50 \mathrm{pg}$.

\section{Statistical analyses}

Statistical analyses were carried out with GraphPad Instat software (Graph-Pad Software, Inc., San Diego, CA, USA). Results are presented as mean \pm SEM and were analyzed with the unpaired Student $t$ test, with $P<$ 0.05 considered statistically significant.

\section{Results}

The human breast cell line MDA-MB-231 was chosen because these ER/PR-negative cells have been shown to exhibit opposing responses to $5 \alpha \mathrm{P}$ and $3 \alpha \mathrm{HP}$ in vitro [18], and because they have the capacity to form tumors spontaneously (without estrogen or progesterone supplements) when implanted into the mammary fat pad of immunodeficient mice [24]. The latter feature was considered important to study the potential of both stimulation and suppression of tumorigenesis. In vitro tests confirmed that proliferation of the passages of MDAMB-231 cells used in the animal trials was significantly stimulated by $5 \alpha \mathrm{P}$ and suppressed by $3 \alpha \mathrm{HP}$ (Figure 2).

\section{ER/PR-negative breast cell tumorigenesis and tumor} growth are stimulated by $5 \alpha \mathrm{P}$ and suppressed by $3 \alpha \mathrm{HP}$ To test the potential of $5 \alpha \mathrm{P}$ to stimulate ER/PR-negative breast tumor formation and growth, 11 mice, 6 weeks old, were divided into two groups, five controls and six treated (Figure 3A). Three days (day -3) before cell implantation, they received a single injection of either vehicle (controls) or vehicle containing $5 \alpha \mathrm{P}$ (Figure 3A, inset). The day of cell inoculation was considered as day 0 , and the trial was terminated on day 40 . In three of five controls and in six of six $5 \alpha$ P-treated mice, tumors developed. In the controls, small palpable tumors were first detected in two mice on day 28 and in the third mouse on day 32 . Of the $5 \alpha \mathrm{P}$-treated mice, two had palpable tumors on day 21 , and all six, by day 27 . The tumors in the six $5 \alpha$ P-treated mice grew more rapidly and were on average 4.2-fold larger at termination than the three tumors in the control mice $(P<0.05)$. The results showed that incidence, onset, and growth of ER/ PR-negative human breast cell tumors are stimulated by the progesterone metabolite, $5 \alpha \mathrm{P}$.

To determine whether $5 \alpha \mathrm{P}$ and $3 \alpha \mathrm{HP}$ have opposing actions on ER/PR-negative breast cell tumor formation, 24 mice were divided into four groups of six mice each and injected twice (on day -2 and day 12) with vehicle (control), or vehicle containing either $5 \alpha \mathrm{P}, 3 \alpha \mathrm{HP}$, or $5 \alpha \mathrm{P}+3 \alpha \mathrm{HP}$ (Figure 3B). In the control group, a palpable

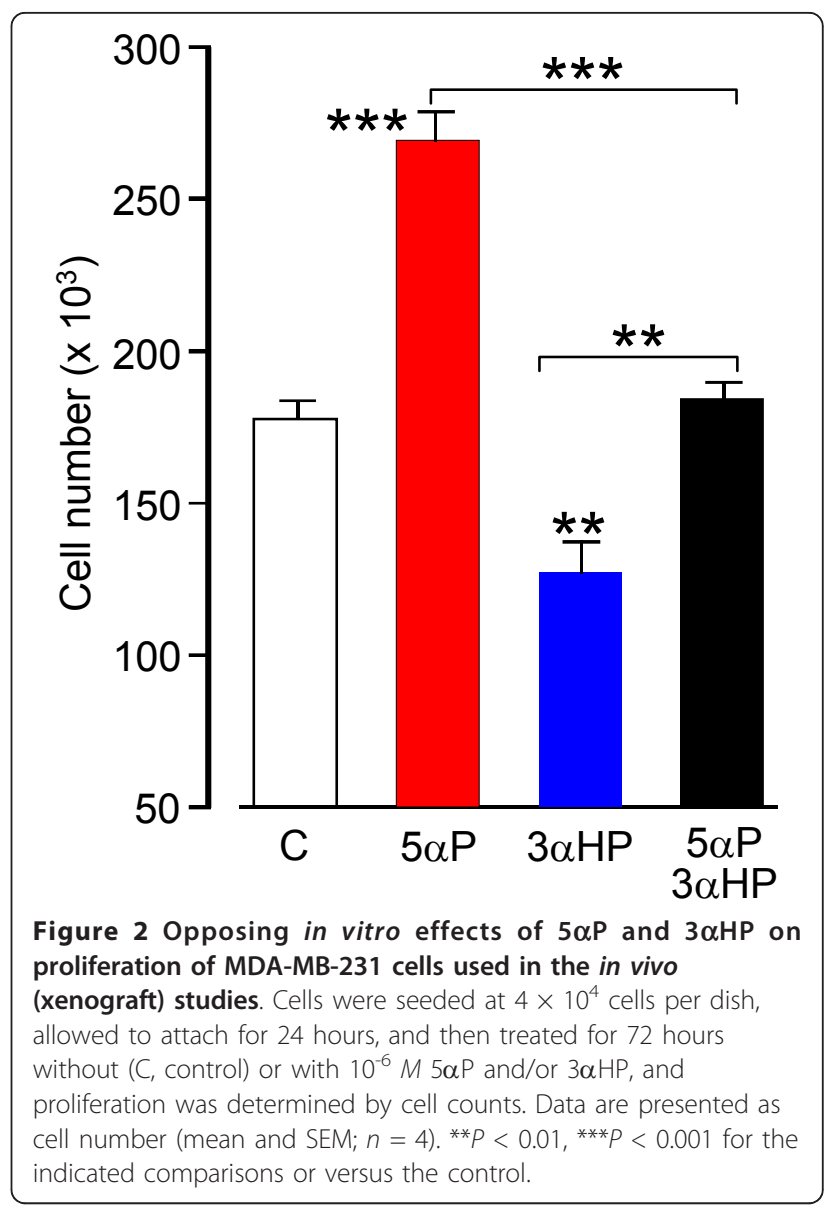

tumor was observed in one mouse on day 33 and in four others by day 39 , and the tumor size (mean \pm SEM) was $164.4 \pm 40.2 \mathrm{~mm}^{3}$ on day 46 and $409.8 \pm 73.8 \mathrm{~mm}^{3}$ at termination (day 59). In the $5 \alpha$ P-treated group, two mice had palpable tumors by day 20 , four by day 23 , and all six by day 33 ; the tumors developed very rapidly, so that by day 46 , the tumor volume was $2,431.8 \pm 374.4 \mathrm{~mm}^{3}(14.8$ fold larger than in the controls; $P<0.001$ ), and the tumor burden required termination of this group. In the $3 \alpha \mathrm{HP}-$ treated group, palpable tumors were detected in two mice on day 37 and in two other mice by day 41, with average size of $69.2 \pm 6.6 \mathrm{~mm}^{3}$ on day 46 , and $159.6 \pm 32.1 \mathrm{~mm}^{3}$ on day 59 , significantly smaller $(P<0.05)$ than those in the controls. In the group treated with $3 \alpha \mathrm{HP}+5 \alpha \mathrm{P}$, palpable tumors were detected in two mice on day 35 and in three more on day 39 , with average size of $351.6 \pm 43.3$ $\mathrm{mm}^{3}$ on day 46 , and $1,020 \pm 140 \mathrm{~mm}^{3}$ on day 59 . In comparison with the $5 \alpha \mathrm{P}$-only treated group, the results of the combined treatment $(3 \alpha \mathrm{HP}+5 \alpha \mathrm{P})$ showed that $3 \alpha \mathrm{HP}$ significantly suppressed the $5 \alpha \mathrm{P}$-induced onset and growth of tumors $(P<0.001)$; tumor volume was 11.3 -fold smaller than in the $5 \alpha \mathrm{P}$-only group on day 46 . Conversely, $5 \alpha \mathrm{P}$ significantly countered the suppressive action of $3 \alpha \mathrm{HP}$ in the $5 \alpha \mathrm{P}+3 \alpha \mathrm{HP}$ group $(P<0.01)$; the tumor volume in the 

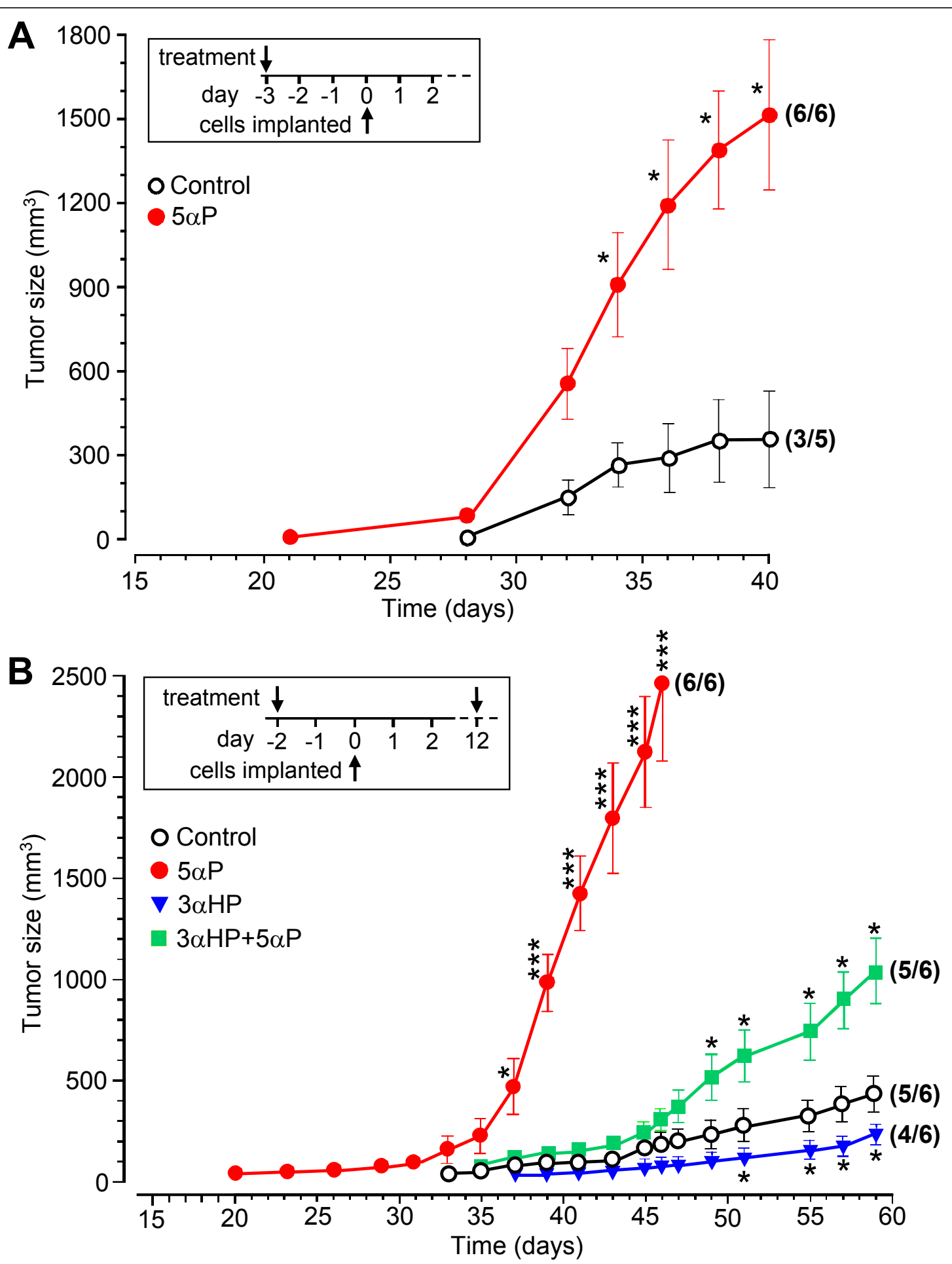

Figure 3 ER/PR-negative breast cell tumor induction and growth are regulated by $5 \alpha \mathrm{P}$ and $3 \alpha \mathrm{HP}$. (A) Tumor induction and growth are stimulated by $5 \alpha$ P. MDA-MB-231 cells were implanted in mammary fat pads of 11 mice (day 0, inset); 3 days before (day -3), five mice were injected with vehicle (control; black open circles), and six were injected with $5 \alpha \mathrm{P}$ (red, solid circles). Data points represent size ( $\mathrm{mm}^{3} ; \mathrm{mean}^{ \pm}$ SEM) of tumors that developed of a total number of mice per treatment (bracketed values), and the experiment was terminated on day 40. *Significantly different from controls at $P<0.05$. (B) Tumor induction and growth are stimulated by $5 \alpha \mathrm{P}$ and inhibited by $3 \alpha \mathrm{HP}$. Twenty-four mice were divided into four groups of six mice each, and MDA-MB-231 cells were implanted on day 0 (inset). Two days before (day -2) and on day 12, mice were injected with either vehicle (control; black open circles), $5 \alpha \mathrm{P}$ (red, solid circles), $3 \alpha \mathrm{HP}$ (blue inverted triangles), or $5 \alpha \mathrm{P}+3 \alpha \mathrm{HP}$ (green squares). The $5 \alpha$ P-treated mice were terminated on day 46 because of tumor burden, and the other mice were terminated on day 59 . Data points represent size $\left(\mathrm{mm}^{3}\right.$; mean \pm SEM) of tumors that developed of a total number of mice per treatment (bracketed values). Significantly different from controls at ${ }^{*} P<0.05$ and ${ }^{* *} P<0.001$. 
combined-treatment group was 4.7-fold larger than that in the $3 \alpha \mathrm{HP}$-only treated group on day 59 . The experiment was repeated (see Additional file 3), and the overall results confirmed that $5 \alpha \mathrm{P}$ treatment stimulated, whereas $3 \alpha \mathrm{HP}$ inhibited, tumor initiation and growth, whereas simultaneous treatment with both hormones $(3 \alpha \mathrm{HP}+5 \alpha \mathrm{P})$ resulted in abrogation of the effects of either hormone alone.

\section{$3 \alpha \mathrm{HP}$ results in suppression and regression of $5 \alpha \mathrm{P}$ - stimulated ER/PR-negative breast tumors}

These experiments showed that the stimulatory effects of $5 \alpha \mathrm{P}$ and the inhibitory effects of $3 \alpha \mathrm{HP}$ are abrogated when the two hormones are given simultaneously, starting near the time of cell implantation. Two experiments were conducted to determine whether $3 \alpha \mathrm{HP}$ can suppress and/ or reverse the tumorigenic effects initiated by prior treatments with $5 \alpha \mathrm{P}$. The first experiment (Figure 4A) was conducted to determine if multiple treatments with $3 \alpha \mathrm{HP}$ over an extended period result in a higher level/incidence of suppression of tumorigenesis. Fourteen mice were treated with $5 \alpha \mathrm{P}$ on day -3 and day 11 , and then seven of these mice continued to be treated with $5 \alpha \mathrm{P}$ (Group I), whereas the other seven (Group II) were treated with $3 \alpha \mathrm{HP}$ on days 27, 36, and 47 (Figure $4 \mathrm{~A}$, inset). Two mice were excluded from the final analysis: one from Group I, which failed to develop a tumor, and one from Group II, which started to develop an aggressive tumor just 9 days after the first treatment with $3 \alpha \mathrm{HP}$ (about 5 to 6 weeks before the onset of any other tumor). At termination (day 96), all (six of six) of Group I mice had tumors (1,034.4 \pm $399.1 \mathrm{~mm}^{3}$ ), and none (none of six) of Group II mice had tumors, indicating more-marked suppression of $5 \alpha \mathrm{P}$-stimulated tumorigenesis by multiple $3 \alpha \mathrm{HP}$ treatments.

The second experiment (Figure 4B) was conducted to determine whether $3 \alpha \mathrm{HP}$ can reverse the tumorigenic effects initiated by prior treatments with $5 \alpha \mathrm{P}$. Twentyfour mice received three subcutaneous injections (days 0 , 20 , and 61 ) of $5 \alpha \mathrm{P}$. Then, on day 75,14 mice with similar-sized small palpable tumors ( 18 to $34 \mathrm{~mm}^{3}$ ) were divided into two groups, consisting of seven mice each, which received one injection of either vehicle (control) or $3 \alpha \mathrm{HP}$ (Figure 4B, inset). At termination 24 days later, all seven of the control mice had enlarged tumors (950.9 \pm $277.6 \mathrm{~mm}^{3}$ ), whereas of the seven $3 \alpha \mathrm{HP}$-treated mice, four had regressed to either no palpable tumors or just tiny nodules $\left(\leq 5 \mathrm{~mm}^{3}\right)$, and three had relatively small tumors $\left(333.7 \pm 90.1 \mathrm{~mm}^{3}\right)$, indicating marked suppression and regression of $5 \alpha \mathrm{P}$-induced tumors by treatment with $3 \alpha \mathrm{HP}$.

Effect of treatments on health and condition of animals and on tumor histopathology

At termination of experiments, mice from all treatment groups appeared to be in good body condition; no significant differences were noted in body-weight gain and in general appearance and condition of liver, lung, kidney, heart, and adrenals between control mice and mice from different treatments. Mice with enlarged tumors were observed to have some enlargement of the pancreas and spleen. The large $5 \alpha \mathrm{P}$-stimulated tumors tended to extend from the right ventral mammary fat pad area and laterally to the dorsal thoracic area near the steroid depots (Figure 5A). Histopathologic analyses of tumors from $5 \alpha \mathrm{P}$-treated mice showed hypercellular solid carcinomas invading the muscle and other outer aspects of the thoracic cavity (Figure 5B) and exhibited frequent mitoses (Figure $5 \mathrm{C}$ ). In contrast, residual tumors in $3 \alpha \mathrm{HP}$-treated mice (Figure 5D) showed little or no invasion into surrounding tissue (Figure $5 \mathrm{E}$ ) and generally exhibited less-frequent mitoses and more-frequent multifocal necroses (Figure 5F).

\section{Concentrations of $5 \alpha \mathrm{P}$ and $3 \alpha \mathrm{HP}$ in serum and tumors Validation of RIA measurements by mass spectrometry}

To determine the levels of $5 \alpha \mathrm{P}, 3 \alpha \mathrm{HP}$, and progesterone in serum and tumors, RIAs specific for these steroids were used. For validation of the RIA measurements, aliquots of TLC-separated $5 \alpha \mathrm{P}, 3 \alpha \mathrm{HP}$, and progesterone extracts from four tumors were tested with both RIA and gas chromatography-mass spectrometry (GC-MS). The results showed no significant differences between RIA and GC-MS measurements of hormone levels (see Additional file 2) and provided validation of the reliability of the RIA measurements.

\section{Serum levels of $3 \alpha H P$ and $5 \alpha P$ are elevated after hormone} treatments

To determine whether steroid treatments resulted in increased concentrations in the circulation, serum samples from vehicle (control) and hormone-injected mice were analyzed for $5 \alpha \mathrm{P}$ and $3 \alpha \mathrm{HP}$ at 15 to 22 days and 42 days after the last treatment (Figure 6A). Although $5 \alpha \mathrm{P}$ and $3 \alpha \mathrm{HP}$ concentrations were about the same ( 2 to 3 $\mathrm{ng} / \mathrm{ml}$ ) at both time periods in the vehicle-injected mice, the concentrations were significantly higher (about threefold to sixfold) in treated mice at 15 to 22 days after hormone injections and had declined to control levels by 42 days.

\section{Levels of $5 \alpha P$ are higher in serum from control mice with} tumors than in those without tumors

Measurements of hormone levels in serum of control animals (vehicle only) at termination showed that the $5 \alpha \mathrm{P}$ concentrations were significantly higher $(P<0.05)$ in mice with tumors than in mice without tumors (Figure 6B). Also, in serum from control mice with tumors, the concentrations of $5 \alpha \mathrm{P}$ were significantly higher $(P<0.01)$ than the concentrations of $3 \alpha \mathrm{HP}$, resulting in significantly higher $5 \alpha \mathrm{P} / 3 \alpha \mathrm{HP}$ ratios $(P<0.01)$ than in serum from mice without tumors (Figure $6 \mathrm{C}$ ). 

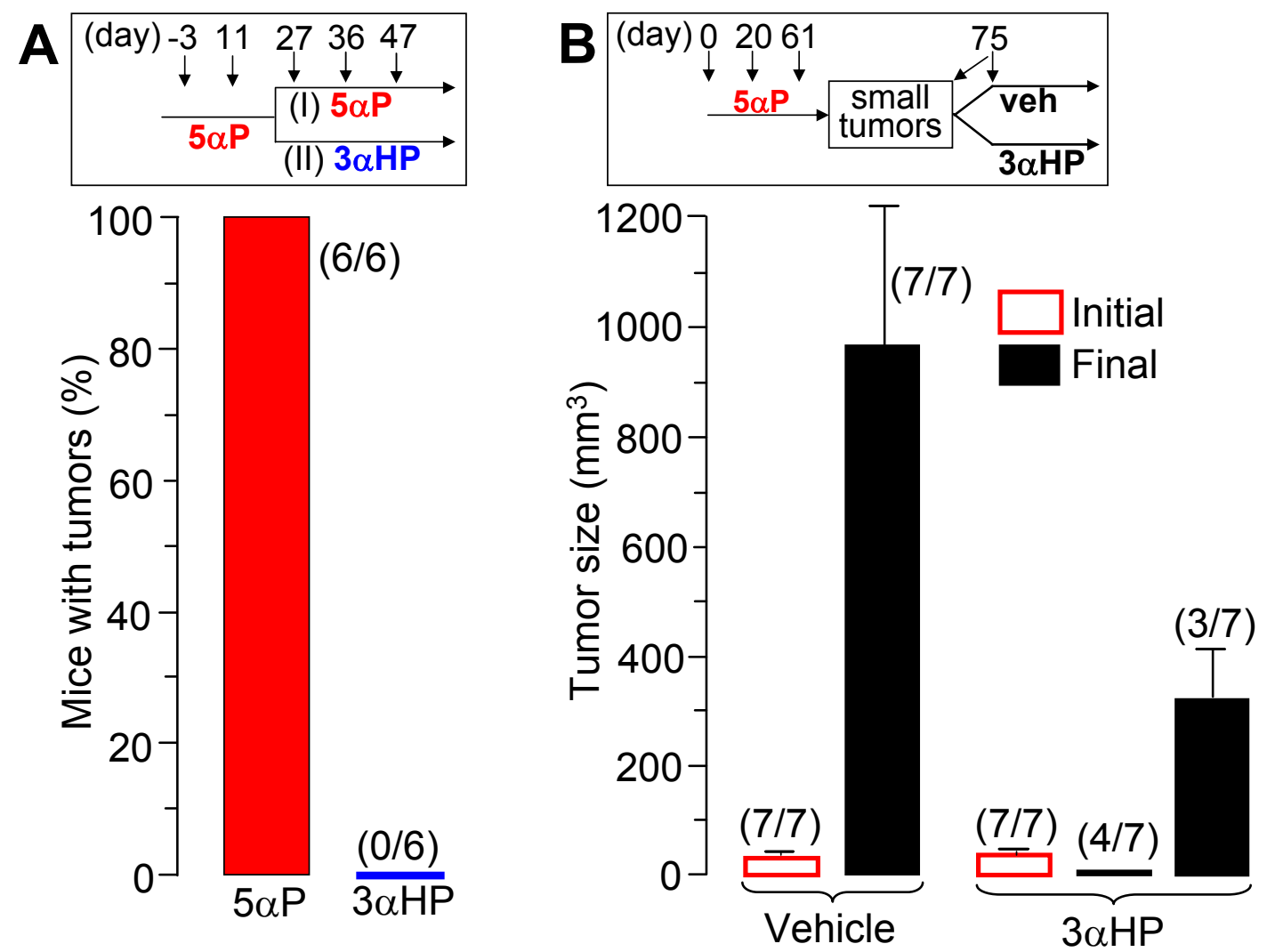

Figure $43 \alpha \mathrm{HP}$ results in suppression and regression of $5 \alpha \mathrm{P}$-induced ER/PR-negative tumors. (A) $3 \alpha \mathrm{HP}$ suppresses ER/PR-negative breast cell tumorigenesis in $5 \alpha \mathrm{P}$-pretreated mice. Fourteen mice were treated with $5 \alpha \mathrm{P}$ on day -3 and day 11 and then were divided into two groups. One group (Group I) continued to be treated with $5 \alpha \mathrm{P}$, whereas the other group (Group II) was treated with $3 \alpha \mathrm{HP}$ on days 27, 36, and 47 (Inset). One mouse from each group was excluded from the final analysis, as explained under Results. The data are presented as the percentage of mice with tumors at termination. (B) $3 \alpha \mathrm{HP}$ results in regression of $5 \alpha \mathrm{P}$-induced ER/PR-negative breast cell tumors. Twenty-four mice with MDA-MB-231 cell implants received injections of $5 \alpha \mathrm{P}$ on days 0,20 , and 61 (inset); on day 75, the 14 mice with approximately similar-sized small palpable tumors (18 to $34 \mathrm{~mm}^{3}$ ) were divided into two groups, consisting of seven mice each, which received a single injection of either vehicle (veh) or $3 \alpha \mathrm{HP}$, and the experiment was terminated 24 days later. Bars represent size $\left(\mathrm{mm}^{3}\right.$; mean $\pm \mathrm{SEM}$ ) of tumors that developed of a total number of mice per treatment (bracketed values), at the start of treatments (day 75, Initial) and at termination (day 99, Final).

\section{Tumors have higher levels of $5 \alpha P$ than $3 \alpha H P$ and higher $5 \alpha P / 3 \alpha H P$ concentration ratios than serum}

To determine whether levels of $5 \alpha \mathrm{P}$ and $3 \alpha \mathrm{HP}$ in tumors are affected by hormone treatments, tumors from mice that had received vehicle, $5 \alpha \mathrm{P}$, or $3 \alpha \mathrm{HP}$ injections before tumor initiation were analyzed at termination (Figure 7A). The results showed no significant differences in tumor hormone levels due to treatments. All the tumors had significantly higher levels of $5 \alpha \mathrm{P}$ (about 10 -fold) than $3 \alpha \mathrm{HP}(P<0.01)$, and the $5 \alpha \mathrm{P} /$ $3 \alpha \mathrm{HP}$ ratios were not significantly different between tumors from mice with different treatments (Figure 7B). To compare hormone concentrations in tumors and respective sera, levels of $5 \alpha \mathrm{P}, 3 \alpha \mathrm{HP}$, and progesterone were determined in samples from nine tumorous mice (Figure 7C). The levels of $5 \alpha \mathrm{P}$ were significantly higher $(P<0.01)$, and those of $3 \alpha \mathrm{HP}$ were significantly lower $(P<0.01)$ in tumors than in serum, whereas the progesterone levels did not differ significantly. In tumors, the concentrations of $5 \alpha \mathrm{P}$ were on average more than 10-fold higher than those of $3 \alpha \mathrm{HP}$, and the $5 \alpha \mathrm{P} / 3 \alpha \mathrm{HP}$ ratios were more than fivefold greater than in the respective sera (Figure $7 \mathrm{D} ; P<0.001)$. Significantly higher levels of $5 \alpha \mathrm{P}$ than of $3 \alpha \mathrm{HP}$ were also confirmed in samples from the four tumors analyzed with mass spectrometry (Additional file 2).

\section{Discussion}

"receptor-negative" breast cancers fail to benefit from current hormonal therapies, but they also generally exhibit more-aggressive biologic behaviors and poorer prognosis than the receptor-positive ones [10-14]. The results of the studies reported here show for the first time that the progesterone metabolites, $5 \alpha \mathrm{P}$ and $3 \alpha \mathrm{HP}$, act as hormones that regulate ER/PR-negative breast tumor formation, growth, and regression. The onset of the ER/PR-negative 


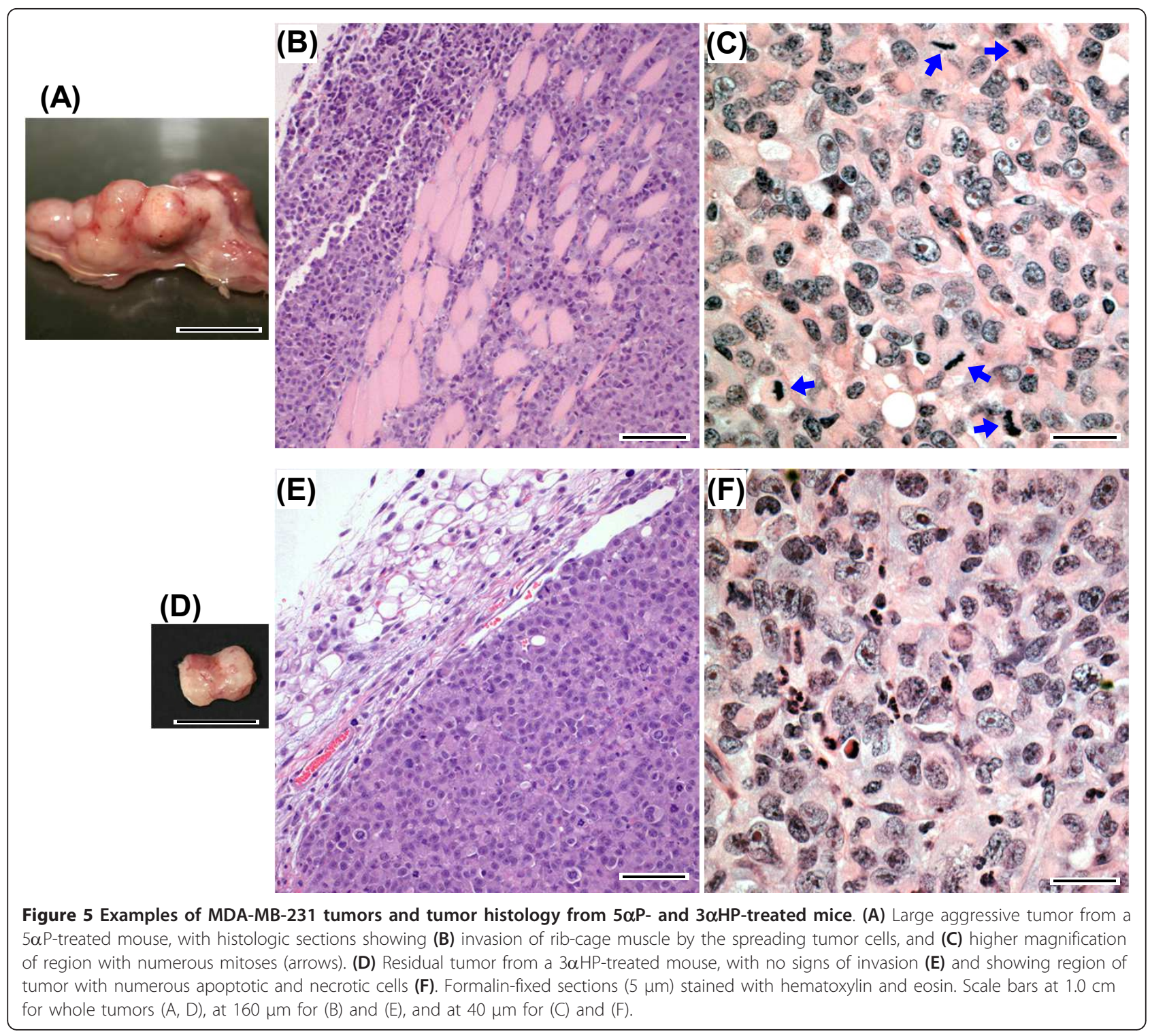

human breast cell tumors in mice was considerably accelerated, and the growth significantly stimulated, by just one or two applications of $5 \alpha \mathrm{P}$. In contrast, $3 \alpha \mathrm{HP}$ retarded onset of tumor formation, suppressed tumor growth, and inhibited or regressed existing $5 \alpha \mathrm{P}$-induced tumors. When both hormones were administered simultaneously, the effects of one were abrogated by the effects of the other. The current in vivo demonstrations, from five separate experiments, of the opposing actions of $5 \alpha \mathrm{P}$ and $3 \alpha \mathrm{HP}$ on tumorigenesis and tumor growth extend the previous findings, which showed opposing in vitro cancerregulatory actions of these progesterone metabolites on receptor-negative (MDA-MB-231, MCF-10A) as well as receptor-positive (MCF-7, T47D, ZR-75-1) breast cell lines $[15,17,18]$.
The response of ER/PR-negative breast cells to the progesterone metabolites can be explained by the presence of specific high-affinity receptors for $5 \alpha \mathrm{P}$ ( $5 \alpha \mathrm{PR}$ ) and $3 \alpha \mathrm{HP}(3 \alpha \mathrm{HPR})$. The $5 \alpha \mathrm{PR}$ and $3 \alpha \mathrm{HPR}$ (which are associated with the plasma membranes of both ER/PRpositive [19] and ER/PR-negative [29] cells) are distinct from each other and from known ER, PR, androgen, and corticosteroid receptors, and lack affinity for other steroids, such as progesterone, estrogen, androgens, corticosteroids, and other progesterone metabolites [19]. Levels of $5 \alpha \mathrm{PR}$ are upregulated by $5 \alpha \mathrm{P}$ itself and estradiol, and downregulated by $3 \alpha \mathrm{HP}$ in both ER/PR-positive and -negative cells [29]. The mechanisms of action resulting in the opposing effects of these two hormones appear to involve cell-signaling pathways associated with 


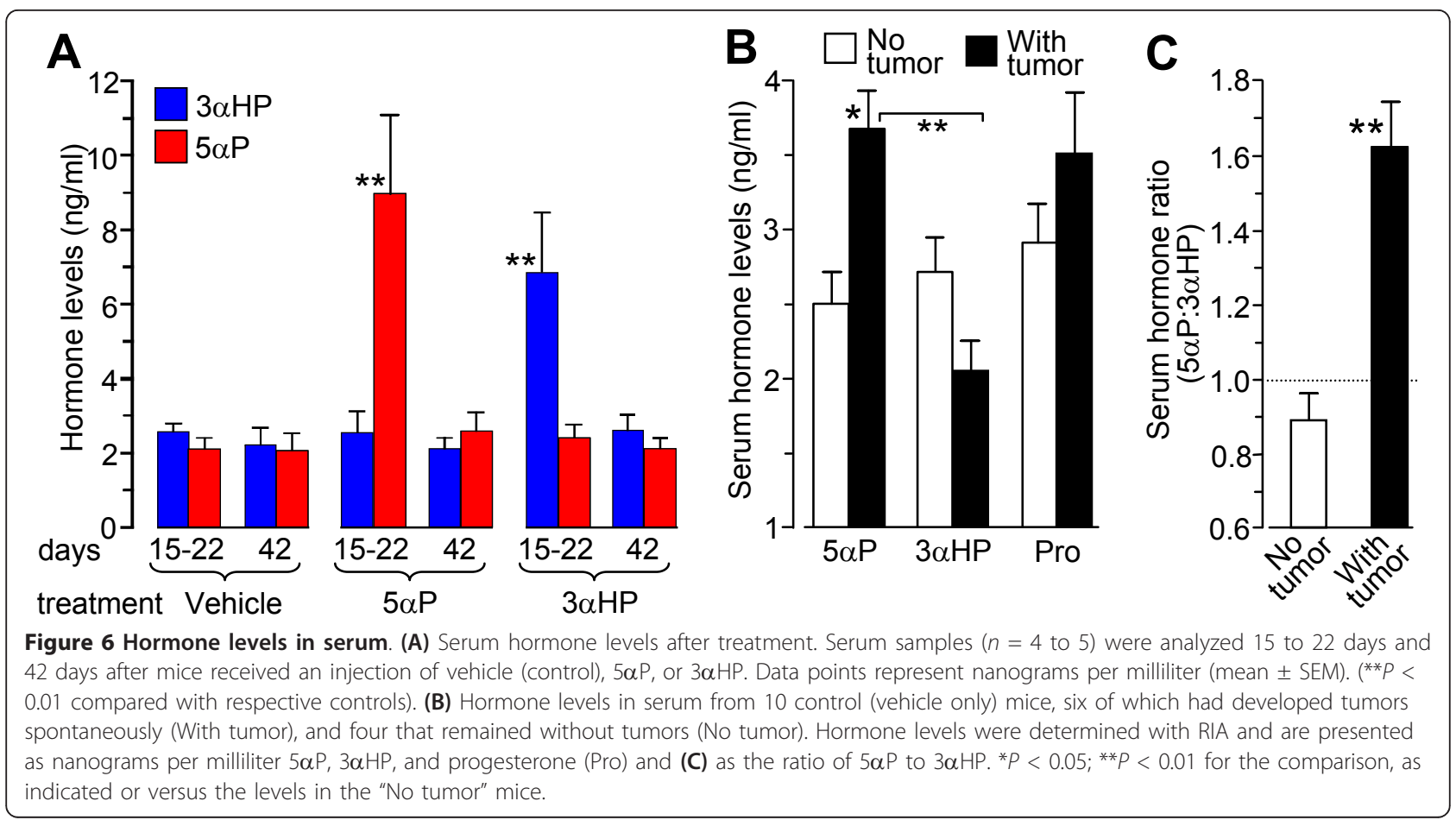

the plasma membrane receptors, as well as altered gene expression. Indications are that $5 \alpha \mathrm{P}$ acts via the surface receptor-linked mitogen-activated protein kinase (MAPK; Erk1/2) pathway; $5 \alpha \mathrm{P}$ significantly stimulates activation of Erk1/2 [30], increases the Bcl-2/Bax expression ratio [18] and actin depolymerization [31], and decreases expression of actin and adhesion plaque-associated vinculin [31], resulting in decreased apoptosis and increased mitosis and cell detachment. Conversely, $3 \alpha \mathrm{HP}$ appears to suppress protein kinase $\mathrm{C}(\mathrm{PKC})$, phospholipase $\mathrm{C}$ (PLC), $\mathrm{Ca}^{2+}$ mobilization (unpublished observations), and the Bcl-2/ Bax expression ratio [18], and increases expression of the cell-cycle inhibitor p21 [18], resulting in increased apoptosis and decreased proliferation and detachment of breast cell lines. In pituitary cells, $3 \alpha \mathrm{HP}$ also has been shown to inhibit a plasma membrane-associated PKC, PLC, $\mathrm{Ca}^{2+}$ cell-signaling pathway [32].

The results of the studies reported here not only show that $5 \alpha \mathrm{P}$ and $3 \alpha \mathrm{HP}$ have opposing effects on initiation and growth of ER/PR-negative human breast tumors, but also provide in vivo evidence of the marked changes in the relative concentrations of these hormones in the tumor microenvironment. Whereas serum from control mice, in which implanted human breast cells had not developed into tumors, contained about equal concentrations of $5 \alpha \mathrm{P}$ and $3 \alpha \mathrm{HP}$, serum from mice with tumors had significantly more $5 \alpha \mathrm{P}$ than $3 \alpha \mathrm{HP}$. Because hormones had not been administered to these mice, the higher $5 \alpha \mathrm{P} / 3 \alpha \mathrm{HP}$ ratio in serum from tumor-bearing mice can reasonably be expected to have resulted from the tumors, which on average had about threefold higher concentrations of $5 \alpha \mathrm{P}$ than the respective sera, and $>10$-fold higher $5 \alpha \mathrm{P}$ than $3 \alpha \mathrm{HP}$ levels. Previous in vitro metabolism studies showed that human breast tumor tissues convert significantly more progesterone to $5 \alpha$-pregnanes like $5 \alpha \mathrm{P}$ and less to 4-pregnenes like $3 \alpha \mathrm{HP}$ than do paired normal (nontumorous) tissues [15] and that these differences correlated with significantly higher $5 \alpha$-reductase gene (SRD5A1, SRD5A2) and lower $3 \alpha(20 \alpha)$-HSO gene (AKR1C1, AKR1C2, AKR1C3) progesterone metabolism and enzyme gene expressions were observed between tumorigenic and nontumorigenic breast cell lines [16]. In addition to the ability to convert progesterone to active cancer-regulating hormones, breast carcinomas are able to synthesize progesterone $[34,35]$, which could account for its relatively high concentrations in the xenograft tumors reported here, and indicate an in situ supply of the biosynthetic precursor of $5 \alpha \mathrm{P}$ and $3 \alpha \mathrm{HP}$.

The significant concentrations of $5 \alpha \mathrm{P}$ and $3 \alpha \mathrm{HP}$, and particularly the high $5 \alpha \mathrm{P} / 3 \alpha \mathrm{HP}$ ratios, in the MDA-MB231 xenograft tumors, emphasize the potential importance of the microenvironment within breast tissue where the biologic actions occur. The role of the microenvironment in changing the expression of regulatory factors such as metabolizing enzymes, receptors, cytoskeletal and adhesion molecules, and growth promoters/inhibitors and in expression in tumor tissues [33]. Similar differences in 

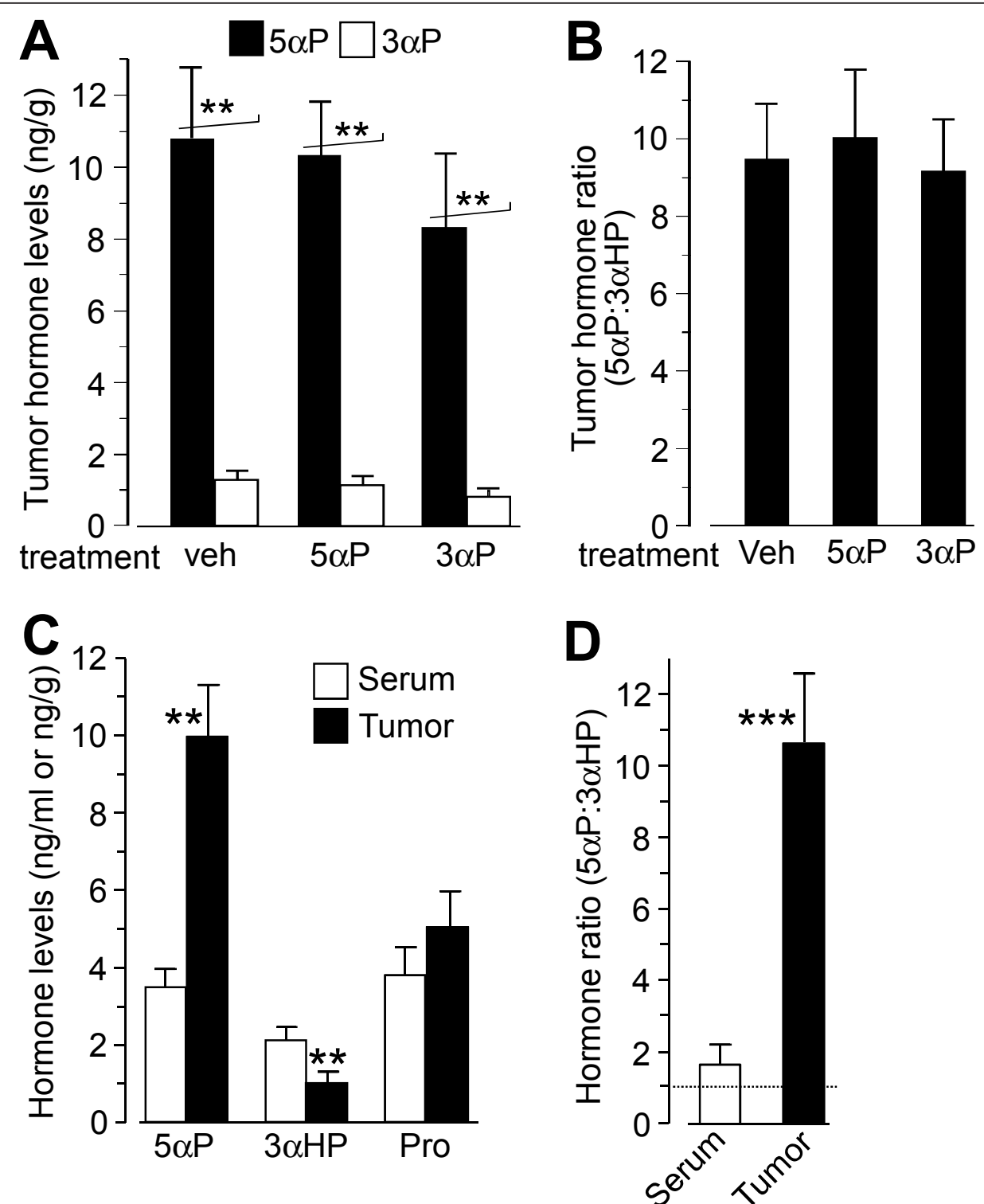

Figure 7 Hormone levels in tumors. (A) Effect of hormone treatment on $5 \alpha \mathrm{P}$ and $3 \alpha \mathrm{HP}$ levels in tumors. Hormone levels in tumors from four vehicle-injected, five $5 \alpha \mathrm{P}$-treated, and four $3 \alpha \mathrm{HP}$-treated mice were determined with RIA, as described in Methods. Hormone levels are presented as nanograms per milliliter $5 \alpha \mathrm{P}$ and $3 \alpha \mathrm{HP}$ and (B) as the ratio of $5 \alpha \mathrm{P}$ to $3 \alpha \mathrm{HP}$. ( ${ }^{* * P}<0.01$ for the comparison between $5 \alpha \mathrm{P}$ and $3 \alpha \mathrm{HP}$ levels). (C) Levels of $5 \alpha \mathrm{P}, 3 \alpha \mathrm{HP}$, and progesterone (Pro) in tumors and respective sera from nine mice were determined after extraction with organic solvents and separation by thin-layer chromatography (TLC) as described in Methods. Levels of hormones are presented as nanograms per milliliter (serum) and nanograms per milligram (tumors), and (D), as the ratio of $5 \alpha \mathrm{P}$ to $3 \alpha \mathrm{HP}$. ${ }^{* *}$, ***ignificantly different from serum levels at $P<0.01$ and $P<0.001$, respectively.

epigenetic alterations has been extensively reviewed [36-40]. The current findings, along with the previous in vitro studies, suggest that the relative concentrations of $5 \alpha \mathrm{P}$ and $3 \alpha \mathrm{HP}$ in the breast microenvironment constitute important autocrine/paracrine determinants not only for tumorigenesis but also for potential regression of tumors and the maintenance of normalcy of ER/PR-negative breast cells/tissues. Figure 8 provides a summary of opposing biologic actions and proposed mechanisms of action of the progesterone metabolites, $5 \alpha \mathrm{P}$ and $3 \alpha \mathrm{HP}$, in promoting neoplasia and tumorigenesis, as well as in maintaining normalcy in ER/PR-negative human breast cells. Evidence presented here shows that a high concentration of $5 \alpha \mathrm{P}$, relative to $3 \alpha \mathrm{HP}$ in the microenvironment, promotes initiation and growth of tumors, whereas a higher concentration of $3 \alpha \mathrm{HP}$, relative to $5 \alpha \mathrm{P}$, suppresses tumorigenesis and promotes normalcy. Previous evidence indicates that these opposing effects of $5 \alpha \mathrm{P}$ and $3 \alpha \mathrm{HP}$ are propagated 


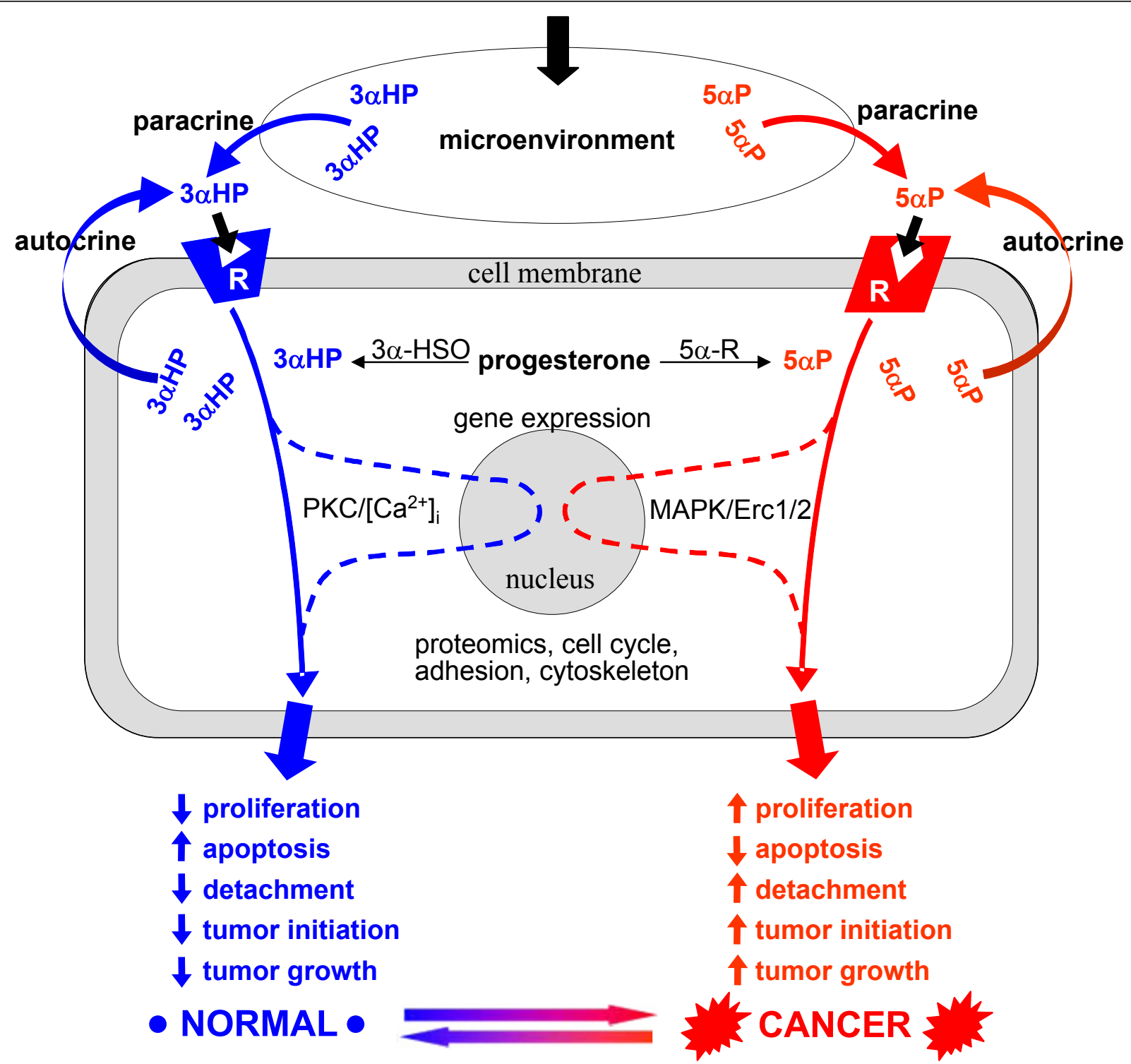

Figure 8 Summary of the opposing autocrine/paracrine effects of the progesterone metabolites, $5 \alpha \mathrm{P}$ and $3 \alpha \mathrm{HP}$, in a stylized ER/PRnegative human breast cell. Evidence presented here shows that a high concentration of $5 \alpha \mathrm{P}$ relative to $3 \alpha \mathrm{HP}$, in the microenvironment, promotes initiation and growth of ER/PR-negative human breast cell tumors, whereas a higher concentration of $3 \alpha \mathrm{HP}$, relative to $5 \alpha \mathrm{P}$, suppresses tumorigenesis and promotes normalcy. Progesterone is converted to $3 \alpha \mathrm{HP}$ and $5 \alpha \mathrm{P}$ in breast cells. Tumorigenic and tumor cells convert more progesterone to $5 \alpha \mathrm{P}$ and less to $3 \alpha \mathrm{HP}$ than do normal cells. The steroids, being lipophylic, are able to pass out of cells and result in a concentration buildup in the microenvironment. The result is a significant increase in the $5 \alpha \mathrm{P}$-to-3 $\alpha \mathrm{HP}$ concentration ratio in the microenvironment of tumorigenic cells and within tumorous tissues in comparison with normal (nontumorous) breasts. $3 \alpha \mathrm{HP}$ and $5 \alpha \mathrm{P}$ bind to specific receptors on the plasma membrane linked to signaling pathways involving PKC, phospholipase $\mathrm{C}$, and $\mathrm{Ca}^{2+}$ mobilization (3aHP) and MAPK/Erk1/2 (5 $\alpha \mathrm{P})$ and to modulators of gene expression. The cancer-inhibiting actions of $3 \alpha \mathrm{HP}$ result in decreased proliferation and detachment of cells, increased apoptosis, and suppression of tumor initiation and growth. The cancer-promoting actions of $5 \alpha \mathrm{P}$ have the opposite effects and result in stimulation of tumorigenesis and tumor growth. The evidence suggests that high concentrations of $5 \alpha \mathrm{P}$ relative to $3 \alpha \mathrm{HP}$ in the microenvironment will promote progression toward neoplasia and tumorigenesis, whereas a low $5 \alpha \mathrm{P}$-to-3 $\alpha \mathrm{HP}$ concentration ratio favors maintenance of the normal state.

via the opposing actions of the hormones on cell proliferation (mitosis, apoptosis), adhesion, cell cycle, regulatory and signaling molecules, and gene expression after binding to specific receptors.
How might higher levels of either $5 \alpha \mathrm{P}$ or $3 \alpha \mathrm{HP}$ in the serum due to the steroid implants have, respectively, initiated/promoted or suppressed xenograft tumorigenesis? The $5 \alpha \mathrm{P}$ and $3 \alpha \mathrm{HP}$ treatments, consisting of 
suspensions placed subcutaneously in the nape of the neck, resulted in elevated serum levels of either hormone, which persisted for about 2 to 3 weeks after the last injection. Because the depots were not far removed from the site of the cell implants, lymph drainage may have resulted in significantly higher concentrations of each applied hormone in the immediate vicinity of the implanted human cells. Conceivably, in the $5 \alpha$ P-treated mice, the induced elevation of $5 \alpha \mathrm{P}$ levels, relative to $3 \alpha \mathrm{HP}$, in the microenvironment of the human cell implants, could have exerted procancer actions that initiated tumorigenesis. Because $5 \alpha$-reductase and $5 \alpha$ PR levels are upregulated by $5 \alpha \mathrm{P}$ [29], the in situ production and paracrine/autocrine actions of locally elevated $5 \alpha \mathrm{P}$ could then have autoenhanced hormone-receptor interaction and the resulting stimulation of tumor growth, as illustrated in Figure 8. In a like manner, in the $3 \alpha \mathrm{HP}$-treated mice, the elevated $3 \alpha \mathrm{HP}$ levels, relative to $5 \alpha \mathrm{P}$, in the microenvironment could have opposed progression to xenograft neoplasia by its inherent anticancer actions and the suppression of $5 \alpha \mathrm{P}$ synthesis and $5 \alpha \mathrm{PR}$ expression [29]. By extension, in an intact human breast, local changes in relative concentrations of $5 \alpha \mathrm{P}$ and $3 \alpha \mathrm{HP}$ (that is, changes in the $5 \alpha \mathrm{P} /$ $3 \alpha \mathrm{HP}$ ratio) resulting from selective up- or downregulation of progesterone-metabolizing enzymes induced by microenvironmental triggers could determine ER/PRnegative breast cell progression to tumor initiation and growth or maintenance of normalcy. Because only small changes in enzyme activity/expression are needed to result in significant local concentration changes, either a slight elevation of $5 \alpha$-reductase, or a reduction of $3 \alpha$ HSO, in one or more cells could lead to an increase in the ratio of $5 \alpha \mathrm{P} / 3 \alpha \mathrm{HP}$ in the immediate intra- and extracellular environment. Conversely, processes that result in higher levels of cancer-suppressing $3 \alpha \mathrm{HP}$ (and consequently lower $5 \alpha \mathrm{P} / 3 \alpha \mathrm{HP}$ ratios) could ensure maintenance of normalcy.

Because in vitro studies have shown that both ER-and/ or PR-negative and -positive breast cells respond in a stimulatory and inhibitory fashion, respectively, to $5 \alpha \mathrm{P}$ and $3 \alpha \mathrm{HP}$, and have $5 \alpha \mathrm{PR}$ and $3 \alpha \mathrm{HPR}$, the present results also may have implications for the substantial numbers (20\% to $40 \%$ ) of ER/PR-positive patients who fail to respond to suppression of estrogen and/or progesterone levels or actions $[4,41,42]$, as well as for those receptorpositive tumors that do respond to hormonal therapies. In this regard, the opposing actions of the progesterone metabolites also appear to exert some control over the estrogen-regulated effects on breast cancer by their ability to modulate ER numbers in ER-positive cells [43]. Furthermore, because both tumorigenic and normal (nontumorigenic) breast cells respond to the opposing actions of $5 \alpha \mathrm{P}$ and $3 \alpha \mathrm{HP}$, the relative concentrations of the progesterone metabolites in the microenvironment may also play a role in maintaining normalcy of breast tissues in general, regardless of ER/PR status.

\section{Conclusions}

In vivo evidence shows that the progesterone metabolites, $5 \alpha \mathrm{P}$ and $3 \alpha \mathrm{HP}$, control tumorigenesis of ER/PRnegative human breast cells: $5 \alpha \mathrm{P}$ stimulates, whereas $3 \alpha \mathrm{HP}$ suppresses, initiation and growth of tumors. Although both hormones can be synthesized by breast cells/tissues, tumors produce significantly more $5 \alpha \mathrm{P}$ than $3 \alpha \mathrm{HP}$, resulting in high $5 \alpha \mathrm{P} / 3 \alpha \mathrm{HP}$ ratios in the breast microenvironment. The findings provide the first hormonal explanation of the regulation of ER/PR-negative breast tumors. The results suggest new hormonal biomarkers, diagnostics, and therapeutics for these aggressive "receptor-negative" breast tumors that are unresponsive to current hormonal therapies. Moreover, because both ER/PR-negative and ER/PR-positive, as well as normal and tumorigenic human breast cell lines, have been shown to respond to $5 \alpha \mathrm{P}$ and $3 \alpha \mathrm{HP}$ in vitro, it is suggested that these endogenously produced progesterone metabolites may also play regulatory hormonal roles in ER/PR-positive breast cancers, as well as in the maintenance of normalcy in nontumorous breast tissues. The in vivo data provide further evidence that progesterone metabolites, such as $5 \alpha \mathrm{P}$ and $3 \alpha \mathrm{HP}$, deserve to be considered as active hormones in their own right, rather than inactive waste products, and that they must be considered in the development of new approaches to prevention, detection, and treatment of breast cancers.

\section{Additional material}

\section{Additional file 1: Mass spectrometry (GC-MS) of $3 \alpha \mathrm{HP}, 5 \alpha \mathrm{P}$, and progesterone.}

Additional file 2: Comparison of hormone measurements with radioimmunoassay (RIA) and GC-MS.

Additional File 3: Additional experiment showing the opposing effects of $5 \alpha \mathrm{P}$ and $3 \alpha \mathrm{HP}$ on ER/PR-negative breast cell tumorigenesis and growth. (Similar to Figure 3).

\section{Abbreviations}

5aP: 5a-pregnane-3:20-dione (5a-dihydroprogesterone); 3aHP: 4-pregnen-3aol-20-one (3a-dihydroprogesterone); 5aPR: 5aP receptor; 3aHPR: 3aHP receptor; ER: estrogen receptor; GC-MS: gas chromatography mass spectrometry; HSO: hydroxysteroid oxidoreductase; HPLC: high-performance liquid chromatography; MAPK: mitogen-activated protein kinase; MAPK/Erc: MAPKVextracellular signal-regulated kinase; PKC: protein kinase C; PLC: phospholipase C; PR: progesterone receptor; RIA: radioimmunoassay; TLC: thin-layer chromatography.

\section{Authors' contributions}

JPW conceived of the study, created the study design, performed mass spectrometry and radioisotope $\left(\left[{ }^{3} \mathrm{H} 5 \mathrm{aP}\right.\right.$ and $\left.\left[{ }^{3} \mathrm{H}\right] 3 \mathrm{aHP}\right)$ syntheses, prepared figures, and assisted in animal studies, data analyses, and hormone measurements, and drafted the manuscript. GZ helped in the study design, 
performed the in vitro proliferation studies, participated in the xenograft studies, hormone preparation, RIA measurements, and literature review. IW was involved in the xenograft studies, performed histopathologic analyses, prepared figures, and assisted in editing the manuscript. HTC carried out the animal studies, surgically implanted the cells, performed the hormone treatments, tumor necropsies, growth measurements and analyses, and helped in generating antibodies for $5 \mathrm{aP}$ used in the RIA. All authors read and approved the final manuscript.

\section{Competing interests}

The authors declare that they have no competing interests.

\section{Acknowledgements}

Assistance with maintaining cell cultures, performing hormone extractions, and in vitro tests was provided by Biljana Popovic and Jordan Jarvis. Critical reading of, and helpful comments and suggestions on the manuscript were provided by Dr. Kathleen Hill (Department of Biology, The University of Western Ontario). The research was supported by grants to JPW from the Canadian Institutes of Health Research and Canadian Breast Cancer Research Alliance and from Susan G. Komen for the Cure.

\section{Author details}

${ }^{1}$ Department of Biology, The University of Western Ontario, London, Ontario, N6A5B7 Canada. ${ }^{2}$ Department of Anatomy \& Cell Biology, Schulich School of Medicine \& Dentistry, The University of Western Ontario, London, Ontario, N6A 5C1 Canada. ${ }^{3}$ Department of Animal Care \& Veterinary Services and Department of Physiology and Pharmacology, Medical Sciences Building, The University of Western Ontario, London, Ontario, N6A 5C1 Canada. ${ }^{4}$ Department of Animal Care \& Veterinary Services, Medical Sciences Building, The University of Western Ontario, London, Ontario, N6A 5C1 Canada.

Received: 3 December 2012 Revised: 16 April 2013

Accepted: 11 May 2013 Published: 11 May 2013

\section{References}

1. American Cancer Society: Global Cancer Facts \& Figures. 2 edition. Atlanta, American Cancer Society; 2011 [http://www.cancer.org/acs/groups/content/ @epidemiologysurveilance/document/acsp-027766.pdf]

2. Key TJ, Pike MC: The role of estrogens and progestogens in the epidemiology and prevention of breast cancer. Eur J Cancer Clin Oncol 1988, 24:29-43.

3. Henderson BE, Feigelson HS: Hormonal carcinogenesis. Carcinogenesis 2000, 21:427-433.

4. McGuire WL, Osborne CK, Clark GM, Knight WA III: Steroid hormone receptors and carcinoma of the breast. Am J Physiol 1982, 243:E99-E102.

5. Aaltomaa S, Lipponen $P$, Eskelinen $M$, Kosma VM, Marin S, Alhava E, Syrjanen K: Hormone receptors as prognostic factors in female breast cancer. Ann Med 1991, 6:643-648.

6. Howat JMT, Harris M, Swindell R, Barnes DM: The effect of oestrogen and progesterone receptors on recurrence and survival in patients with carcinoma of the breast. Br J Cancer 1985, 51:263-270.

7. Taucher S, Rudas M, Gnant M, Thomanek K, Dubsky P, Roka S, Bachleitner T, Kandioler D, Wenzel C, Steger G, Mittlböck M, Jakesz R: Sequential steroid hormone receptor measurements in primary breast cancer with and without intervening primary chemotherapy. Endocr Relat Cancer 2003, 10:91-98.

8. Rexhepaj E, Brennan DJ, Holloway P, Kay EW, McCann AH, Landberg G, Duffy MJ, Jirstrom K, Gallagher WM: Novel image analysis approach for quantifying expression of nuclear proteins assessed by immunohistochemistry: application to measurement of oestrogen and progesterone receptor levels in breast cancer. Breast Cancer Res 2008, 10:R89.

9. Robinson GW, Hennighausen L, Johnson PF: Side-branching in the mammary gland: the progesterone-Wnt connection. Genes Dev 2000, 14:889-894.

10. Paone JF, Abeloff MD, Ettinger DS, Arnold EA, Baker PR: The correlation of estrogen and progesterone receptor levels with response to chemotherapy for advanced carcinoma of the breast. Surg Gynecol Obstet 1981, 152:70-74

11. Vollenweider-Zerargui $L$, Barrelet $L$, Wong $Y$, Lemarchand-Béraud $T$, Gómez F: The predictive value of estrogen and progesterone receptors' concentrations on the clinical behavior of breast cancer in women: clinical correlation on 547 patients. Cancer 1986, 57:1171-1180.
12. Fisher B, Redmond C, Fisher ER, Caplan R: Relative worth of estrogen or progesterone receptor and pathologic characteristics of differentiation as indicators of prognosis in node negative breast cancer patients: findings from National Surgical Adjuvant Breast and Bowel Project Protocol B-06. J Clin Oncol 1988, 7:1076-1087.

13. Bardou V-J, Arpino G, Elledge RM, Osborne CK, Clark GM: Progesterone receptor status significantly improves outcome prediction over estrogen receptor status alone for adjuvant endocrine therapy in two large breast cancer data bases. J Clin Oncol 2003, 21:1973-1979.

14. Dunnwald LK, Rossing MA, Li Cl: Hormone receptor status, tumor characteristics, and prognosis: a prospective cohort of breast cancer patients. Breast Cancer Res 2007, 9:R6, doi:10.1186/bcr 1639

15. Wiebe JP, Muzia D, Hu J, Szwajcer D, Hill SA, Seachrist JL: The 4-pregnene and 5 a-pregnane progesterone metabolites formed in nontumorous and tumorous breast tissue have opposite effects on breast cell proliferation and adhesion. Cancer Res 2000, 60:936-943.

16. Wiebe JP, Lewis MJ: Activity and expression of progesterone metabolizing 5a-reductase, 20a-hydroxysteroid oxidoreductase and $3 a(\beta)$-hydroxysteroid oxidoreductases in tumorigenic (MCF-7, MDA-MB231, T-47D) and nontumorigenic (MCF-10A) human breast cancer cells. BMC Cancer 2003, 3:9.

17. Wiebe JP: Progesterone metabolites in breast cancer. Endocr Relat Cancer 2006, 13:717-738.

18. Wiebe JP, Beausoleil M, Zhang G, Cialacu V: Opposing actions of the progesterone metabolites, $5 \mathrm{a}$-dihydroprogesterone $(5 \mathrm{aP})$ and $3 \mathrm{a}$ dihydroprogesterone (3aHP) on mitosis, apoptosis, and expression of BCL-2, Bax and p21 in human breast cell lines. J Steroid Biochem Mol Biol 2010, 118:125-132.

19. Weiler PJ, Wiebe JP: Plasma membrane receptors for the cancerregulating progesterone metabolites, 5a-pregnane-3,20-dione and 3ahydroxy-4-pregnen-20-one in MCF-7 breast cancer cells. Biochem Biophys Res Commun 2000, 272:731-737.

20. Wiebe JP, Barr KJ, Buckingham KD: A radioimmunoassay for the regulatory allylic steroid, 3a-hydroxy-4-pregnen-20-one (3aHP). J Steroid Biochem Mol Biol 1991, 38:505-512.

21. Erlanger BF, Borek F, Beiser SM, Lieberman S: Steroid-protein conjugates: preparation and characterization of conjugates of bovine serum albumin with testosterone and with cortisone. J Biol Chem 1957, 228:713-727.

22. Naar J, Branaa P, Chinain M, Pauillac S: An improved method for the microscale preparation and characterization of hapten-protein conjugates: the use of cholesterol as a model for nonchromophore hydroxylated haptens. Bioconjugate Chem 1999, 10:1143-1149.

23. Wiebe JP, Deline C, Buckingham KD, Dave V, Stothers JB: Synthesis of the allylic gonadal steroids, 3a-hydroxy-4-pregnen-20-one and 3a-hydroxy-4androsten-17-one, and of 3a-hydroxy-5a-pregnan-20-one. Steroids 1985, 45:39-51.

24. Price JE, Polyzos A, Zhang RD, Daniels LM: Tumorigenicity and metastasis of human breast carcinoma cell lines in nude mice. Cancer Res 1990, 50:717-721.

25. Osborne CK, Yochmowitz MG, Knight WA, McGuire WL: The value of estrogen and progesterone receptors in the treatment of breast cancer. Cancer 1980, 46:2884-2888.

26. Ciocca DR, Elledge R: Molecular markers for predicting response to tamoxifen in breast cancer patients. Endocrine 2000, 13:1-10.

27. Jiang S-Y, Jordan VC: Growth regulation of estrogen receptor-negative breast cancer cells transfected with complementary DNAs for estrogen receptor. J Natl Cancer Inst 1992, 84:580-591.

28. Lin VCL, Eng AS, Hen NE, Ng EHL, Chowdhury SH: Effect of progesterone on the invasive properties and tumor growth of progesterone receptor-transfected breast cancer cells MDA-MB-231. Clin Cancer Res 2001, 7:2880-2886.

29. Pawlak KJ, Zhang G, Wiebe JP: Membrane 5a-pregnane-3,20-dione (5aP) receptors in MCF-7 and MCF-10A breast cancer cells are up-regulated by estradiol and $5 \mathrm{aP}$ and down-regulated by the progesterone metabolites, 3a-dihydroprogesterone and 20a-dihydroprogesterone, with associated changes in cell proliferation and detachment. J Steroid Biochem Mol Biol 2005, 97:278-288.

30. Wiebe JP, Lewis MJ, Cialacu V, Pawlak KJ, Zhang G: The role of progesterone metabolites in breast cancer: potential for new diagnostics and therapeutics. J Steroid Biochem Mol Biol 2005, 93:201-208.

31. Wiebe JP, Muzia D: The endogenous progesterone metabolite, 5apregnane-3,20-dione, decreases cell-substrate attachment, adhesion 
plaques, vinculin expression, and polymerized F-actin in MCF-7 breast cancer cells. Endocrine 2001, 16:7-14.

32. Beck CA, Wolfe M, Murphy LD, Wiebe JP: Acute, nongenomic actions of the neuroactive gonadal steroid, 3a-hydroxy-4-pregnen-20-one (3aHP), on FSH release in perifused rat anterior pituitary cells. Endocrine 1997, 6:221-229.

33. Lewis MJ, Wiebe JP, Heathcote JG: Expression of progesterone metabolizing enzyme genes (AKR1C1, AKR1C2, AKR1C3, SRD5A1, SRD5A2) is altered in human breast carcinoma. BMC Cancer 2004, 4:27.

34. Abul-Hajj YJ, Iverson R, Kiang DT: Metabolism of pregnenolone by human breast cancer: evidence for 17alpha-hydroxylase and 17,20-lyase. Steroids 1979, 34:817-827.

35. Gunasegaram R, Peh KL, Loganath A, Ratnam SS: Expression of 3ßhydroxysteroid dehydrogenase-5,4-en isomerase activity by infiltrating ductal human breast carcinoma in vitro. Breast Cancer Res Treat 1998, 50:117-123.

36. Sutherland RM: Cell and environment interactions in tumor microregions: the multicell spheroid model. Science 1988, 240:177-184

37. Kenny PA, Bissell MJ: Tumor reversion: correction of malignant behavior by microenvironmental cues. Int I Cancer 2003, 107:688-695.

38. Hayashi S-I, Yamaguchi Y: Estrogen signaling pathway and hormone therapy. Breast Cancer 2008, 15:256-261.

39. Hu M, Polyak K: Molecular characterization of the tumor microenvironment in breast cancer. Eur J Cancer 2008, 44:2760-2765.

40. Wilson C, Holen I, Coleman RE: Seed, soil and secreted hormones: potential interactions by breast cancer cells with their endocrine/ paracrine microenvironments and implications for treatment with bisphosphonates. Cancer Treat Rev 2012, 38:877-889.

41. Fuqua SA: Where is the lesion in hormone-independent breast cancer? In J Natl Cancer Inst. Volume 84. Bethesda; 1992:554-555.

42. Murphy LC: Mechanisms of hormone independence in human breast cancer. In Vivo 1998, 12:95-106

43. Pawlak KJ, Wiebe JP: Regulation of estrogen receptor (ER) levels in MCF-7 cells by progesterone metabolites. I Steroid Biochem Mol Biol 2007, 107:172-179.

\section{doi:10.1186/bcr3422}

Cite this article as: Wiebe et al:: Progesterone metabolites regulate induction, growth, and suppression of estrogen- and progesterone receptor-negative human breast cell tumors. Breast Cancer Research 2013 15:R38.

\section{Submit your next manuscript to BioMed Central and take full advantage of:}

- Convenient online submission

- Thorough peer review

- No space constraints or color figure charges

- Immediate publication on acceptance

- Inclusion in PubMed, CAS, Scopus and Google Scholar

- Research which is freely available for redistribution 